\title{
Moleküler Beslenme Çalışmaları ve Diyetisyen
}

\author{
Molecular Nutrition Studies and Dietitian
}

\section{Prof. Dr. Türkan Kutluay Merdol ${ }^{1}$}

\section{Gíriş}

Son iki dekadlık dönemde nanoteknoloji, nütrigenetik, epigenetik gibi alanlarda yaşanan gelişmeler çerçevesinde bireysel beslenme modellerinin geliştirilmesi büyük bir gerek haline gelmiş ve beslenmelerinin planlanmasını isteyen bireylere bu anlamda hizmet verecek sağlık personeli talebi de buna paralel olarak artmıştır.

Sağllk ve beslenme alanında bu gelişmeler yaşanırken besin sanayiinde de önemli gelişmeler olmuş, bir yandan hazır besin üretimleri yapımı ve satışı yüksek oranlara ulaşırken, bir yandan da her tür hastalıkta kullanılabilecek ve tedaviye destek veren çeşitli diyet ürünleri ve solüsyonları da geliştirilmeye başlanmıştır. Bu alanda öne çıkan pek çok firma yurdumuzda da şubeler açmaya başlamış ve bu kurumlarda çalıştırılacak İngilizce bilen diyetisyen ilanlarına başlamışlardır. Tüm bu gelişmelerin ışığında diyetisyene gereksinim artmıştır. Amerika Birleşik Devletleri’nde İşgücü İstatistikleri Bürosu (Bureau of Labor Statistics, BLS) 2012-2022 yılı için diyetisyen istihdamı artışının \%21 olacağını öngörmüştür. Halen Türkiye'de beslenme ve diyetetik eğitimi alan diyetisyenlerin büyük bir bölümü hastanelerde ve eğitim kurumlarında görev yapmaktadır. Toplu beslenme yapılan kurumlar, diyaliz üniteleri, toplum sağlığı merkezleri, besin üretim firmaları, diyet ürünü satan ilaç firmaları gibi kurumlar diyetisyen aramakta ancak bu alanlara atayacak diyetisyen bulamamaktadırlar.
Sağlığın değerlendirilmesinde ve uygulanacak tedavilerde, beslenme odaklı fizik muayene (Nutrition Focused Physical Exam, NFPE) olarak adlandirılan muayene yöntemi kliniklerde yaygınlaşmaya başlamıştır. Buna paralel olarak tıbbi ekip içinde diyetisyenin rolü de giderek artmaktadır. Tedavi, hastanın hastanede yatış süresini kısaltmada çok etken olan diyet planlarının hastanın özellikleri dikkate alınarak planlanmasını zorunlu kılmaktadır. Her toplumda giderek artan obezite ve buna bağlı olarak gelişen metabolik hastalıkların önlenmesinde başarı oranı oldukça düşüktür. Çünkü geliştirilen yöntemler bireye özgü değildir, oysa araştırmalar diyet, egzersiz ve ilaç tedavisine cevabın her bireyde aynı olmadığını artık açıkça ortaya koymaktadır. Beslenme bilimi evrildikçe, bu alanda hizmet verenlerin, özellikle diyetisyenlerin, kişilerin genetik yapılarının tedaviye cevaplarını nasıl etkilediği konusunda bilimsel olarak ortaya konulan gelişmeleri daha fazla dikkate almaları gerektiği bir zorunluluk haline gelmiştir. Bu bağlamda gelişen nütrigenetik, nütrigenomik ve epigenomik çalışmalarla, moleküler beslenme adı ile açılan yeni alanda da çalışmalar yoğunlaşmıştır. Hastanın diyet tedavisinde görev alacak diyetisyenlerin bu alanlarda yapılan yayınları izleyebilmesi için bu alanda kullanılan terimlerin Türkçe karşılıklarının doğru yerleştirilmesi ve kullanılması gerekmektedir.

1. Atılım Üniversitesi, Sağllk Bilimleri Fakültesi, Beslenme ve Diyetetik Bölümü, Ankara, Türkiye • E-posta: info@beslenmevediyetdergisi.org (1) https://orcid.org/0000-0002-0783-947X 


\section{Moleküler Beslenme Alanında Kullanılan Terimler} ve Anlamları

Genom (Genome): Bir hücrede bulunan bütün genetik bilgiler genom olarak adlandırılır. Hücre çekirdeğindeki kromozomlarda yer alan deoksiribonükleik asitler (deoxyribonucleic acid, DNA), canlılığımızın sürdürülmesinde, sağlıklı genetik bilgileri koruma ve taşıma gibi önemli bir süreci yürütürler. DNA’lar aracılığı ile yürütülen bu süreç, dergimizin önceki (2018 yıll, 2 nolu sayı) editörden makalesinde geniş olarak anlatılmıştır.

Genomiks (Genomics): Genom diziliminin analizini yapan genetik çalışma alanı.

İnsan Genom Projesi (Human Genome Project): İnsan genom dizilimini ve bu dizilimde yer alan genlerin tanımlanmasını amaçlayan uluslararası araştırma projesi.

Genom Çapında İlişkilendirme Çalışmaları (Genome Wide Association Studies, GWAS): Hastalıklı kişilerde oluşan Tek nükleotid polimorfizmlerin (Single nucleotide polymorphism, SNP) varyasyonlarını tanımlamak amacıyla yapılan araştırmalar. $\mathrm{Bu}$ araştırmalar, tanımlanan genler aracılığı ile bazı hastalıkların gelişebilme riskini belirlemeye yardımcı olabileceği düşünülmektedir.

Genotipleme (Genotyping): Bir organizmanın miras aldığı belirli alelleri ortaya çıkarmak amacıyla yapılan çalışma.

Alel (Allel): Bir genin iki veya daha fazla versiyonundan biridir. Bir birey, her gen için biri anneden biri babadan olmak üzere iki alel miras alır. İki alel aynı ise gen homozigot, aleller farklı ise gen heterozigot olur.

Gen Ekspresyonu (Gene Expression): DNA'mızdaki talimatların (şifrelerin) protein gibi işlevsel bir ürüne dönüştürülme süreci gen ekspresyonu olarak adlandırılır. Protein yapımında iki adım vardır, birincisi transkripsiyon (transcription) ikincisi translasyon (translation)'dur. Bu aşamalardan sonra morfogenez oluşur.
Transkripsiyon (Transcription): DNA'dan RNA sentezi sürecidir. Üretilen bu RNA mesajcı RNA'dır (messenger RNA).

Translasyon (Translation): RNA'dan proteini sentezleme sürecidir. Proteini üretilen hücrede morfogenez oluşur.

Morfogenez (Morphogenesis): Organizmanin şeklinin geliştiği biyolojik süreçtir.

Nütrigenetik (Nutrigenetics) ve Nütrigenomiks (Nutrigenomics): Nütrigenetik ve nütrigenomiks alanları insan genleri ve beslenme arasındaki ilgi üzerine odaklanan çalışma alanlarıdır. Nütrigenomik genlerimiz ile besinler arasında nasıl bir etkileşim olduğunu ve bunun sağlığımızı nasıl etkilediğini araştırır. $\mathrm{Bu}$ alanda yapılan çalışmalara DNA ve SNP testleri gibi moleküler temelli testler yardımcı olmakta, bu test sonuçlarına göre diyetin ve tüketilen besinlerin etkileri incelenmektedir. Bu bağlamda, nütrigenetik bedenin genetik yapısı üzerine besin ögelerinin cevabını incelerken, nütrigenomik besin ögelerinin genlerin ekspresyonunu nasıl etkilediğini incelemektedir.

Epigenetik (Epigenetics): Genetik kodun kendisinin değiştirilmesinden ziyade, gen ekspresyonundaki modifikasyondan kaynaklanan değişikliklerin incelenmesini konu alan çalışma alanı olarak tanımlanmaktadır. Bu alanda oluşan değişikler genelde SNP olarak tanımlanır.

Tek Nükleotid Polimorfizmi (Single Nucleotide Polymorphism, SNP): SNP, kişiler arasındaki genetik varyasyonun tipini gösterir. Bir bireyin genomunda yaklaşık 4-5 milyon SNP olduğu bildirilmektedir. Yakın gelecekte, bu SNP’lerin incelenmesi ile kişinin sağlık durumunun değerlendirilmesinin ve kişiye özel ilaç geliştirilmesinin mümkün olacağına inanılmaktadır.

Homozigot (Homozygote): Homolog (aynı soydan) kromozomlar üzerindeki belirli bir gen löküsünde (pozisyonunda) aynı alellere sahip organizmalar için kullanılan bir terimdir. 
Heterozigot (Heterozygote): Homolog kromozomlar üzerindeki belirli bir gen loküsünde farklı alellere sahip organizmalar için kullanılan bir terimdir.

\section{KAYNAKLAR}

1. Kutluay-Merdol T. Editörden: DNA metilasyonu ve beslenme. Bes Diy Derg 2018;46:(2):103-6.

2. Güleç Ş. Moleküler Beslenme. Tayfur M, editör. Beslenme ve Diyetetik Güncel Konular. 6. Baskı. Ankara; Hatiboğlu Yayınevi, s.177-193. 2018; s.177-93.

3. Dennett $C$. The future of nutrigenomics. Today's Dietitian 2017;19:(10):30-6.

4. Ramos-Lopez O, Milagro FI, Allayee H, Chmurzynska
A, Choi MS, Curi R, De Caterina R, et al. Guide for current nutrigenetic, nutrigenomic and nutriepigenetic approaches for precision nutrition involving the prevention and management of chronic diseases associated with obesity. J Nutrigenet Nutrigenomics 2017;10:(1-2):43-62.

5. Camp KM, Trujillo E. Position of the Academy of Nutrition and Dietetics: nutritional genomics. J Acad Nutr Diet. 2014;114(2):299-312.

6. Sarıgöl, Z. Ündeğer-Bucurgat Ü. Epigenetik değişiklikler ve beslenme ilişkisi. Türkiye Klinikleri J Pharm Sci. 2014; 14:3(2):74-80.

7. Rizzo JM, Buck MJ. Key principles and clinical applications of next-generation DNA sequencing. Cancer Prev Res. 2012;5:(7):887-900. 